\title{
Heat Shock Proteins and Amateur Chaperones in Amyloid-Beta Accumulation and Clearance in Alzheimer's Disease
}

\author{
Micha M. M. Wilhelmus • Robert M. W. de Waal • \\ Marcel M. Verbeek
}

Received: 28 June 2006 / Accepted: 10 November 2006/Published online: 6 July 2007

(C) Humana Press Inc. 2007

\begin{abstract}
The pathologic lesions of Alzheimer's disease (AD) are characterized by accumulation of protein aggregates consisting of intracellular or extracellular misfolded proteins. The amyloid- $\beta(A \beta)$ protein accumulates extracellularly in senile plaques and cerebral amyloid angiopathy, whereas the hyperphosphorylated tau protein accumulates intracellularly as neurofibrillary tangles. "Professional chaperones", such as the heat shock protein family, have a function in the prevention of protein misfolding and subsequent aggregation. "Amateur" chaperones, such as apolipoproteins and heparan sulfate proteoglycans, bind amyloidogenic proteins and may affect their aggregation process. Professional and amateur chaperones not only colocalize with the pathological lesions of $\mathrm{AD}$, but may also be involved in conformational changes of $A \beta$, and in the clearance of $A \beta$ from the brain via phagocytosis or active transport across the blood-brain barrier. Thus, both professional and amateur chaperones may be involved in the aggregation, accumulation, persistence, and clearance of $A \beta$ and tau and in other $A \beta$-associated reactions such as inflammation associated with AD lesions, and may, therefore, serve as potential targets for therapeutic intervention.
\end{abstract}

Keywords Alzheimer's disease · Amyloid · Heat shock proteins · Heparan sulfate proteoglycans - Apolipoproteins . Amyloid beta-protein $\cdot$ Chaperones

M. M. M. Wilhelmus • M. M. Verbeek $(\bowtie)$ Department of Neurology and Alzheimer Centre, Radboud University Nijmegen Medical Centre, 830 LKN, P.O. Box 9101, 6500 HB Nijmegen, Netherlands e-mail: m.verbeek@cukz.umcn.nl

M. M. M. Wilhelmus • R. M. W. de Waal Department of Pathology,

Radboud University Nijmegen Medical Centre,

Nijmegen, Netherlands

\section{Introduction}

Pathological lesions consisting of intra- and/or extracellular accumulations of misfolded proteins are characteristic for neurodegenerative diseases such as Alzheimer's disease (AD). $\mathrm{AD}$ is characterized by three distinct pathological lesions: senile plaques (SPs), neurofibrillary tangles (NFTs), and cerebrovascular amyloid angiopathy (CAA) [1]. Both SPs and CAA are formed by extracellular deposition of aggregated amyloid-beta protein $(A \beta)$, whereas NFTs consist of intracellular aggregates of hyperphosphorylated tau protein in the cytoplasm of neurons [2, $3]$. The $\mathrm{A} \beta$ protein is a $4-\mathrm{kDa}$ proteolytic cleavage product [2] of the transmembrane amyloid- $\beta$ precursor protein (APP). The two major forms of $A \beta$ in human brain are $A \beta_{1-40}$ and $A \beta_{1-42}$, differing from each other only by two amino acids. Cerebral production of $A \beta$ is balanced by clearance from the brain either via active transport across the blood-brain barrier (BBB) or via uptake and degradation of $A \beta$ by microglial cells and astrocytes [4-6]. Active transport of $A \beta$ is mediated by $A \beta$ receptors that are capable of transporting $A \beta$, or $A \beta$ in complex with other proteins, across the BBB [7]. In contrast to normal brain, the cerebral $\mathrm{A} \beta$ balance is disturbed in $\mathrm{AD}$ brains, resulting in accumulation and aggregation of $A \beta$.

$A \beta$ aggregation includes the formation of $A \beta$ oligomers, protofibrils, and eventually, mature fibrils. Both $A \beta$ oligomers and protofibrils are considered the most toxic forms of $A \beta$ that initiate degeneration of neurons and of cells within the vasculature, such as smooth muscle cells and pericytes $[8,9]$. $A \beta$ aggregates do not clear from the brain as efficiently as soluble $A \beta$, and thus, directly lead to increased levels of $A \beta$ in the brain [10]. Furthermore, deposition of $A \beta$ in SPs is accompanied by attraction and activation of both microglial cells and astrocytes [11-13]. Activation of these 
cell types results in increased secretion of pro-inflammatory cytokines as part of a neuro-inflammatory reaction.

Chaperones can be defined as proteins that: (1) have a role in the intracellular handling of misfolded proteins, (2) induce conformational changes of proteins, (3) act as transporter of proteins. "Professional" chaperones, such as the heat shock protein family (Hsp), are defined as proteins that have a specific function in facilitating normal folding of proteins and intracellular handling of misfolded proteins. Members of the Hsp family recognize misfolded proteins and transport them to the proteasome for degradation. Therefore, this protein family acts as the first line of defense against toxicity induced by misfolded proteins such as $A \beta$ and tau. In contrast to professional chaperones, "amateur" chaperones can be defined as proteins that bind to other proteins and induce conformational changes or, alternatively, serve as transporter proteins. Examples of putative amateur chaperones are apolipoprotein E (ApoE), heparan sulfate proteoglycans (HSPGs), and complement factors such as $\mathrm{C} 1 \mathrm{q}$. They have, in contrast to the professional chaperones, primarly an extracellular function. In this paper, we will review the role of both amateur and professional chaperones in the pathogenesis of $\mathrm{AD}$.

\section{A $\beta$-Binding Proteins in Extracellular Interaction with $\mathbf{A} \beta$}

\section{Apolipoproteins}

The apolipoprotein family consists of proteins that conjugate with lipids to form different classes of lipoprotein particles. In human brain, several members of this protein family are expressed, such as apolipoprotein E (ApoE), apolipoprotein $\mathrm{J}$ (ApoJ), and apolipoprotein $\mathrm{D}$ (apoD).

ApoE is a major determinant of lipid transport and metabolism and is expressed in brain by astrocytes, microglia, pericytes, and smooth muscle cells [14-18]. In human, three common isoforms are expressed: apoE2, apoE3, and apoE4 which are all products of alleles at a single gene locus $[19,20]$.

The $\varepsilon 4$ allele of ApoE is the major genetic risk factor for $\mathrm{AD}$, whereas the $\varepsilon 2$ allele appears to be protective against AD [21-24]. As ApoE immunoreactivity was found in extracellular amyloid deposits in subjects with $\mathrm{AD}$, it has been suggested that it affects amyloidogenesis $[25,26]$. In vitro studies provided evidence for a direct interaction of ApoE with $A \beta$ and the formation of stable complexes [27, 28]. Binding of $A p o E$ to $A \beta$ is, however, $A p o E$ isoformdependent $(\varepsilon 2>\varepsilon 3>>\varepsilon 4)[29,30]$ and depends on the degree of lipidation [29]. Lipidation of ApoE also seems a major factor in its effect on $\mathrm{A} \beta$-mediated cellular toxicity [18]. In addition, ApoE 4 promotes the conversion of soluble $A \beta$ into $\beta$-sheet-rich amyloid more than ApoE3 [31-33].
In contrast to its effect on $A \beta$ in vitro where a consistent accelerating effect of $A p o E$ on $A \beta$ aggregation is observed, the effect of ApoE on $A \beta$ deposition in transgenic (Tg) mice studies is less equivocal. In early studies, both $A \beta$ immunoreactivity and amyloid formation were reduced in ApoE knockout mice [31, 32]. In addition, CAA and associated microhemorrhages were also suppressed in ApoE knockout mice [34]. This effect might be due to the absence of ApoE/A $\beta$ complexes [35]. In contrast to the effects of murine ApoE in the early studies, both human ApoE3 and ApoE4 suppressed $A \beta$ deposition in Tg mice [36]. In addition, when these mice aged, ApoE4 induced a tenfold higher deposition of fibrillar $\mathrm{A} \beta$ than ApoE3 [37]. Consistent with these latter results, human ApoE4 accelerated $A \beta$ deposition in APPSwe Tg mice relative to human ApoE3 [38]. In addition, when human ApoE3 or ApoE4 were knocked in in $\mathrm{Tg}$ mice, $\mathrm{A} \beta$ deposition was reduced compared to mice carrying endogenous ApoE at 9 months, and at 15 months, substantial CAA was observed in mice with human ApoE4, but not with human ApoE3, and, in either case, parenchymal $A \beta$ was sparse [39]. Thus isoform- and species-specific differences in $\mathrm{ApoE}$ direct the aggregation or clearance of $\mathrm{A} \beta$. Furthermore, it is suggested that the presence of ApoE facilitates internalization and degradation of $\mathrm{A} \beta$ from brain parenchyma by astrocytes [40] and human ApoE may reduce $A \beta$ deposition in mouse brain by facilitating $A \beta$ transport across the BBB [36]. Although these Tg mice studies seem contradictional, ApoE clearly affects conformational changes of $A \beta$ and functions as an $A \beta$-transporter protein.

Besides colocalization of ApoE with $A \beta$ in AD brains, ApoE is also found within neurons containing NFTs [25] where it is able to interact directly with tau protein [41]. Furthermore, ApoE has an isoform-dependent effect on tau phosphorylation, as ApoE3 binds to tau in vitro, whereas ApoE4 fails to bind tau [42]. In addition, an ApoE4dependent increase in phosphorylated tau has been observed [43-45].

Neuroinflammation in AD comprises both activation of microglial cells and astrocytes and activation of the complement system. $A \beta$ deposits in brain are associated with activated microglia and astrocytes, but also with elevated levels of complement $[5,6,46]$. ApoE may have an anti-inflammatory effect by suppressing microglial and astrocytic activation [47-50]. ApoE-deficient mice demonstrate increased levels of IL- 6 and TNF $\alpha$ after LPS stimulation, suggesting a role of ApoE in inflammatory gene regulation [51]. In addition, ApoE isoform-dependent $(\varepsilon 2<\varepsilon 3<\varepsilon 4)$ differences in nitric oxide (NO) levels have been observed in microglia cells [52]. Transgenic mice expressing the ApoE4 protein isoform show a greater NO production than mice expressing the ApoE3 protein isoform. These data indicate that ApoE4 has a less efficient 
anti-inflammatory affect, and thus, may accelerate the development of AD.

Apolipoprotein J, also known as clusterin or SP-40/40, is a highly conserved heterodimeric secreted glycoprotein expressed in brain by epithelial and neuronal cells [53]. ApoJ colocalizes with fibrillar $A \beta$ deposits, and it is suggested that it prevents misfolding and aggregation of soluble A $\beta$ [54-56]. ApoD is a glycoprotein associated with high-density lipoproteins in human plasma and also has a high expression level in human brain [57], but neither its physiological role nor its ligand has been identified. ApoD levels are increased in the hippocampus of $\mathrm{AD}$ patients and in ApoE-deficient mice [58, 59].

In conclusion, ApoE and ApoJ can be regarded as amateur chaperones that regulate $A \beta$ aggregation in vitro. By accelerating the $A \beta$ aggregation process towards mature fibril formation, (human) ApoE prevents formation of toxic $A \beta$ intermediates such as oligomers and protofibrils, and thus, may have a protective function towards development of $\mathrm{AD}$. Moreover, ApoE protects against the development of AD by suppressing the inflammatory reactions associated with $\mathrm{AD}$ lesions. Besides its role in inducing conformational changes in $A \beta, A p o E$ facilitates $A \beta$ clearance from brain by serving as a transporter molecule of $A \beta$, which will be discussed in paragraph 4.

\section{Heparan Sulfate Proteoglycans}

Proteoglycans are members of a large family of macromolecules with a wide variety of functions ranging from simple physical support to various effects on cell adhesion, motility, proliferation, differentiation, and even tissue morphogenesis. They are composed of linear sulfated polysaccharides (glycosaminoglycans, GAGs), consisting of disaccharide units, covalently bound to a core protein. One of the members of this superfamily is the heparan sulfate proteoglycan (HSPG) family characterized by polymers of repeating disaccharides, $N$-acetylglucosamine and glucuronic acid, which can be subsequently modified by sulfatation [60,61]. HSPGs can be subdivided into a family of extracellular matrix proteins, including perlecan, agrin, and collagen XVIII, and a family of cell surface proteins, including syndecans and glypicans [60, 62].

Ever since GAGs were demonstrated in amyloid deposits, the proteoglycans became of interest in amyloidogenesis. The presence of HSPGs in SPs, CAA, and NFTs in AD brains was already demonstrated in the late 1980s [63-65]. Only when antibodies became available that could identify the various individual HSPG species was it described that perlecan colocalized with all three lesions characteristic of AD brains [65-67]. However, we were not able to confirm these findings $[68,69]$. Furthermore, it was shown that in both diffuse and classic SPs, several other HSPGs were found, such as agrin, glypican 1, and syndecan 1-3, whereas collagen XVIII is only present in classic SPs and CAA [69-72].

These data suggest that HSPGs interact with $\mathrm{A} \beta$, thereby contributing to development or persistence of SPs or CAA. HSPGs isolated from Engelbreth-Holm-Swarm tumor prevented proteolytic breakdown of aggregated $A \beta$ [73]. In addition, both agrin and perlecan directly interacted with $A \beta$ and promoted conversion of non-fibrillar $A \beta$ into fibrillar $A \beta[70,74-76]$. Although the interaction between HSPGs and $A \beta$ is likely mediated predominantly by the sulfate moieties of the GAGs, a role for the protein backbone in $A \beta$ aggregation could not be excluded [77, 78]. As sulfated GAGs were also demonstrated in NFTs in AD brains [79], these macromolecules may also play a role in tangle development. Indeed, sulfated GAGs may induce the formation of paired helical filaments by stimulating tau phosphorylation [80].

As heparan sulfates bind to $A \beta$ and interfere with its fibrillogenesis, they are interesting candidates for therapeutic intervention [81]. GAG mimetics are able to inhibit this binding and may block the formation of $\beta$-pleated sheets and adherence of $A \beta$ to the cell surface [82]. The use of GAG mimetics has already been explored in mouse models where they reduced progression of inflammation-associated amyloidosis [83]. The efficacy of one of these compounds is currently being tested in a human phase III trial.

As exemplified by ApoE, A $\beta$-binding proteins may play a role in the inflammatory reactions in AD brains. Recently, it was demonstrated that the semi-synthetic proteoglycan analogue dextran sulfate blocks activation of the complement cascade [84]. In addition, chondroitin sulfate proteoglycans are also known to bind to $\mathrm{C} 1 \mathrm{q}$ and prevent the formation of the $\mathrm{C} 1$ complex in vitro [85]. By doing so, chondroitin sulfate proteoglycans inhibit normal complement function. Furthermore, heparin has long been regarded as a potential complement inhibitor [86].

In conclusion, HSPGs do not only colocalize with $A \beta$ and tau, but they also contribute to the development of these lesions. The role of HSPGs in A $\beta$ aggregation might even be a protective one. HSPGs prevent the persistence of toxic $A \beta$ forms, e.g., oligomers or protofibrils, and transform them into more harmless aggregates, i.e., the classic senile plaques containing mature $A \beta$ fibrils that are less toxic than the intermediate aggregates. In addition, HSPGs might play a role in the development of AD lesions by inhibiting complement activation. According to the definitions, HSPGs can therefore be regarded as amateur chaperones. Their ability to recognize a variety of proteins may originate from the heterogeneous structure of the heparan sulfate chains. The negatively charged HS chains are structurally heterogeneous and bind a diverse repertoire of proteins, such as amyloid A, protease-resistant prion protein, $\alpha$-synuclein, and tau, providing HSPGs with the 
ability to interact with a wide range of intracellular and extracellular amyloidogenic proteins [61].

\section{Complement Factors}

The complement system is an ancient host defense mechanism which is involved in boosting antibody activity. The system consists of a group of soluble serum proteins C1-C9 and is activated either by immunoglobulin $\mathrm{M}$ or $\mathrm{G}$ bound to a foreign particle or directly by microorganisms. Proteins such as Hageman factor, C4 binding protein, CDS46, CD59, and $\mathrm{C} 1$ inhibitor regulate the complement system. In $\mathrm{AD}$, the complement system is overexpressed and activated [46]. The $\mathrm{A} \beta$ protein itself activates this system, and complement factor concentrations are increased in AD brains [87-89]. $\mathrm{A} \beta$ induces $\mathrm{C} 3$ and $\mathrm{C} 4$ in $\mathrm{AD}$, and elevated levels of the membrane attack complex (MAC) composed of C5-C9 have been observed [90, 91]. In addition, factors such as Hageman factor, C1q, C3, and C5-9 are commonly found in SPs and NFTs $[87,92,93]$. $C 1 q$ is associated with $A \beta$ deposits and directly binds fibrillar $A \beta$ which activates the complement cascade [94]. In contrast, the complement inhibitor ( $\mathrm{C1} \mathrm{INH}$ ) is downregulated in $\mathrm{AD}[95,96]$. Thus, an activated complement system is a general feature observed in AD. However, the contribution of complement to the pathogenesis of $\mathrm{AD}$ is controversial.

On the one hand, it is suggested that complement activation protects against $A \beta$-induced toxicity and even contributes to reducing the accumulation of $A \beta$ in SPs [97]. Transgenic mice expressing complement inhibitors develop increased AD-pathology, whereas increased complement $\mathrm{C} 3$ production was associated with a reduction of $\mathrm{A} \beta$ deposition [97]. Thus, the complement activation in the brain may be beneficial in $\mathrm{AD}$ and possibly also other neurodegenerative diseases [98-100].

However, complement activation may lead to accelerated neurodegeneration as well. Activation of complement in an antibody-independent fashion is achieved by binding of aggregated, but not soluble, $A \beta$ to $C 1 q[12,90,101,102]$. This latter finding suggests that in $\mathrm{AD}$, aggregated $\mathrm{A} \beta$ induces chronic complement activation. Thus, $\mathrm{C} 1$ binding to fibrillar $A \beta$ deposits may precede microglial activation. Both $\mathrm{A} \beta$ and pro-inflammatory stimuli are able to activate microglia, which results in increased $A \beta$ and cytokine production [103]. Furthermore, cultured human microglial cells show an increase in cytokine production after costimulation of $\mathrm{A} \beta$ with $\mathrm{C} 1 \mathrm{q}$ and serum amyloid $\mathrm{P}$ (SAP) [104]. This suggests that microglia may get triggered by both $\mathrm{A} \beta$ - and SP-associated factors such as $\mathrm{C} 1 \mathrm{q}$, which results in the secretion of pro-inflammatory cytokines and $A \beta$, both accelerating neurodegeneration.

Although none of the complement factors directly regulate conformational changes of $\mathrm{A} \beta$, complement activation as a whole plays a role in the $A \beta$ aggregation in vivo. Therefore, complement factors might act as amateur chaperones, although their exact role in $\mathrm{A} \beta$ aggregation remains to be elucidated.

\section{Professional Chaperones}

Heat shock proteins (Hsp) are professional chaperones. They are highly conserved proteins constitutively expressed in most cells under normal conditions where they play a role in cellular metabolism and help normal folding processes [105]. In addition, during cell stress, they bind unfolded proteins to keep them in their native state [105]. Heat shock proteins can be divided into two different families based on size and function: classic Hsps such as Hsp100, Hsp90, Hsp70, Hsp60, and the small heat shock proteins (sHsps). Hsps with a molecular weight of $60 \mathrm{kD}$ or more possess an ATP-binding site and are actively involved in the process of refolding of misfolded proteins [106]. Small Hsps, with a molecular weight of $40 \mathrm{kD}$ or less, lack this ATP-binding site and assist the Hsps in their refolding function [107]. The role of Hsps in misfolded protein recognition and refolding is illustrated in Fig. 1.

\section{Small Heat Shock Proteins}

Small Hsps function as molecular chaperones that can prevent proteins from adopting an incorrect conformation [108]. The sHsp family is characterized by the presence of an $\alpha$-crystallin domain, a stretch of 80-100 amino acids in the $\mathrm{C}$ terminal half of the proteins [109]. So far, the sHsp family comprises ten sHsps, including $\alpha \mathrm{B}$-crystallin, Hsp27, Hsp20, HspB8, and HspB2/B3 [110]. Although sHsps are

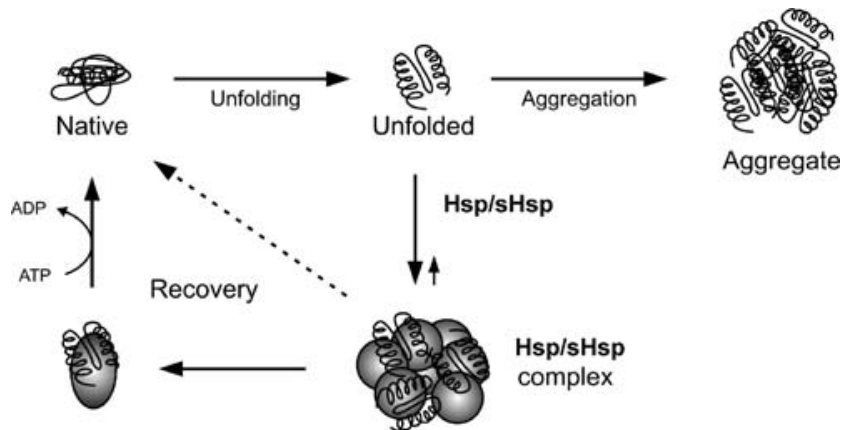

Fig. 1 The role of heat shock proteins $(H s p)$ and small heat shock proteins (sHsps) in recognition and refolding of unfolded and misfolded proteins. Unfolded or misfolded proteins are recognized by Hsps and sHsps. Together with these unfolded or misfolded proteins, Hsps and sHsps form a complex. In addition, Hsps recover unfolded or misfolded proteins back to their native form using ATP. If unfolded or misfolded protein are not recognized by the Hsp/sHsps, these unfolded or misfolded proteins are capable of forming aggregates 
predominantly expressed in muscle cells, several family members are also found in human brain.

In $\mathrm{AD}, \alpha \mathrm{B}$-crystallin and Hsp27 are upregulated and expressed by astrocytes surrounding SPs and NFTs [111114], whereas Hsp20, HspB2, and HspB8 colocalize with $\mathrm{A} \beta$ in SPs and CAA $[115,116]$. Although $\alpha \mathrm{B}$-crystallin or Hsp27 do not colocalize with $A \beta$ in SPs, direct interaction between $A \beta$ and these sHsps in addition to Hsp20 and HspB8 has been demonstrated [111, 117-119]. In addition, high-affinity binding of $\alpha \mathrm{B}$-crystallin and $\mathrm{A} \beta$ has been observed in eye lenses from AD patients [120]. Furthermore, $\alpha \mathrm{B}$-crystallin is able to prevent mature $\mathrm{A} \beta$ fibril formation, retaining it in a non-fibrillar, but likely a protofibrillar state, which is highly toxic to neurons [121]. Recently, we demonstrated that $\alpha \mathrm{B}$-crystallin, Hsp20, and HspB8 inhibit $A \beta$-mediated toxicity towards cerebrovascular cells probably by preventing aggregation of $A \beta$ at the cell surface $[116,117]$. Others showed that Hsp27 directly binds to hyperphosphorylated tau, thereby protecting against cell death [122].

Hsps are involved in the formation and persistence of misfolded protein aggregates. They are upregulated in several neurodegenerative diseases, such as AD, CreutzfeldtJakob disease, and Parkinson's disease probably as a reaction to the formation of misfolded proteins [113, 123-126]. However, despite of increased intracellular levels, they are unable to prevent accumulation of $A \beta$ in $A D$ possibly because of decreased chaperone activity. In aged rats, this was illustrated by a significant decrease of $\mathrm{Hsp} 90$ function [127], resulting in diminished hepatic chaperone capacity. Furthermore, the increasing amount of damaged or misfolded proteins as a result of defects in protein degradation might lead to a total decrease in chaperone activity in aged cells [128]. Thus, the state of misfolded protein recognition and repair systems, such as the (s)Hsp system, might be of great importance in the development of neurodegenerative diseases.

\section{Miscellaneous Proteins}

Apart from the above-described proteins, several other molecules are also associated with the pathological lesions of $\mathrm{AD}$, and some of these can be regarded as amateur chaperones. Acute phase proteins, such as $\alpha_{1}$-antichymotrypsin (ACT), $\alpha_{2}$-macroglobulin $(\alpha 2 \mathrm{M})$, and SAP, are all associated with $A \beta$ deposition [129-132]. ACT is a serine protease inhibitor of the serpin family, and in $\mathrm{AD}, \mathrm{ACT}$ levels are upregulated, and binding of ACT with $A \beta$ induces $A \beta$ fibrillogenesis [133-135]. Furthermore, when ACT is overexpressed in transgenic mice, an increased plaque load in the brains of these mice and impaired spatial learning is observed [134, 135]. $\alpha 2 \mathrm{M}$ also binds $\mathrm{A} \beta$, although in contrast to ACT, this binding prevents $A \beta$ fibril formation and fibril-associated neurotoxicity [136, 137]. $\alpha 2 \mathrm{M}$ promotes the protease-mediated degradation of $\alpha 2 \mathrm{M} /$ $A \beta$ complexes and contributes to clearance of $A \beta$ from the brain (discussed in paragraph 4) [138, 139]. The glycoprotein SAP belongs to the pentraxin family and is a common component of all known types of amyloid fibrils. SAP is upregulated in $\mathrm{AD}$ and protects amyloid fibrils from proteolysis in vitro [140, 141]. SAP not only colocalizes with SPs and interacts with aggregated $\mathrm{A} \beta$; SAP oligomers also bind and activate $\mathrm{C} 1$ [142]. Both $\mathrm{C} 1$ and SAP may bind to fibrillar $A \beta$ deposits in vivo and induce microglial activation, as cultured human microglial cells show an increase in cytokine production after co-stimulation of $A \beta$ with C1q and SAP [104]. These observations further strengthen the above-noted suggestion that not only $A \beta$, but also several $\mathrm{A} \beta$-binding proteins, are capable of activating the complement system, and thus, contribute to neuroinflammation in $\mathrm{AD}$. In addition, both $\alpha 2 \mathrm{M}$ and $\mathrm{ACT}$, in contrast to SAP, can be regarded as amateur chaperones, as they regulate conformational changes of $A \beta$.

Tissue-type plasminogen activator (tPA) regulates activation of plasminogen into plasmin and is expressed in various regions of the brain especially in the hippocampus [143]. Several reports suggested an important role for tPA in $A D$, as the tPA system is involved in $A \beta$ turnover $[144,145]$. Fibrillar forms of $A \beta$ stimulate tPA activity in vitro, whereas in AD patients, a reduction of tPA activity is observed in the affected areas [144, 146]. Although tPA has no effect on conformational changes of $A \beta$, it might play a role in the clearance of $A \beta$ from the brain (paragraph 4].

The actin-regulatory protein gelsolin is found both intracellularly and in plasma [147, 148]. Plasma gelsolin can be considered an amateur chaperone, as it binds $A \beta$ and not only inhibits its $A \beta$ fibrillization but is also capable of degrading preformed $A \beta$ fibrils $[149,150]$. Furthermore, gelsolin inhibits $A \beta$-mediated neurotoxicity [151].

One of the major gangliosides in the brain is GM1. Soluble A $\beta$ binds GM1 and the formed complexes accelerate $A \beta$ fibrillogenesis by acting as a seed for $A \beta$ [152]. In the presence of GM1, $A \beta$ is more neurotoxic than $A \beta$ alone, and cholesterol-rich membranes demonstrate accelerated A $\beta$ binding due to the formation of GM1 clusters [153, 154]. As GM1 is a major component of lipid rafts and recent studies suggest that $A \beta$ accumulation in these lipid rafts is an early event in AD development, GM1 might play an important role in the early steps in $\mathrm{AD}$ pathogenesis $[155,156]$.

In summary, several proteins are associated with $A \beta$ aggregates in the $\mathrm{AD}$ brain and contribute to the aggregation of $A \beta$ and should, therefore, be considered as amateur chaperones. In addition, they might play a role in triggering inflammation. 


\section{$A \beta$-Binding Proteins and Intracellular Interactions with $\mathbf{A} \beta$}

Intracellular accumulation of $A \beta$ already starts in the ER or in the Golgi apparatus of the cell [157-159]. Intracellular $\mathrm{A} \beta$ is associated with neuronal damage [160, 161], and intraneuronal accumulation of $A \beta$ in transgenic mice was correlated with impairments in synaptic plasticity [162]. Intraneuronal accumulation of $A \beta$ in those brain areas affected earliest in AD suggests a possible relation between intracellular $\mathrm{A} \beta$ and development of $\mathrm{AD}$ [160].

A few proteins that interact with intracellular $A \beta$ and affect its intracellular fate have been identified. The endoplasmic reticulum amyloid beta-peptide-binding protein binds intracellular $A \beta$ and mediates neurotoxicity in neuronal cells by forming an intracellular target for $A \beta$ [163]. In addition, the mitochondrial enzyme amyloid- $\beta$ alcohol dehydrogenase also binds $A \beta$ inside neurons, resulting in the production of free radicals [164]. However, whether these intracellular $A \beta$-binding proteins affect aggregation of $A \beta$ within the cells remains unknown. Therefore, both these proteins cannot, for the time being, be defined as amateur chaperones of $A \beta$.

The first lines of defense against misfolded and aggregated proteins are the professional chaperones, which counteract these processes and are able to stimulate clearance of misfolded proteins by proteosomal degradation. Newly synthesized proteins are folded by several other proteins, such as immunoglobulin-binding protein (BiP)/glucoseregulated protein (GRP78), and calnexin. GRP78 is a member of the Hsp70 protein family and interacts with intracellular APP. GRP78 regulates APP and A $\beta$ secretion by intervening between APP and $\beta-/ \gamma$-secretases within the cell [165].

It is not surprising that in $\mathrm{AD}$, where misfolded protein molecules accumulate, both Hsp90 and Hsp70 synthesis is increased. Several members of the Hsp family directly interact with intracellular $A \beta$, but only recently, Hsp70 was identified as a protector against intracellular $A \beta$ accumulation [166, 167]. Besides, immunoreactivity of both Hsp90, 70, and Hsp60 is found in SPs [132], which suggests that these professional chaperones may not only interact with misfolded protein in the cell interior [168171]. In addition, it has also been postulated that upregulation of Hsp90 and Hsp70 may suppress the formation of NFTs by partitioning tau into a productive folding pathway and thereby preventing its aggregation [172]. Recently, it was demonstrated that the chaperone CHIPHsc70 complex conjugates ubiquitin to hyperphosphorylated tau, which enhances cell survival by elimination of soluble hyperphosphorylated tau [173]. These data suggest that the cell increases production of the Hsps to cope with the presence of misfolded proteins such as hyperphos- phorylated tau and accumulating $\mathrm{A} \beta$. At some point, this protective mechanism seems to fail, however. In line with this hypothesis, it was shown that the actin and tubulin specific chaperone Hsp60 is decreased in $\mathrm{AD}$, resulting in a decrease of cytoskeletal proteins in $\mathrm{AD}$-affected neurons [174]. Thus, both production and function of Hsps seems to be disturbed in $\mathrm{AD}$, which might result in the accumulation of misfolded proteins. The role of other Hsps in regulating intracellular $A \beta$ or tau folding remains to be investigated (Table 1).

\section{$A \beta$-Binding Proteins and $A \beta$ Clearance}

$\mathrm{A} \beta$-binding proteins, amateur chaperones, play a role in the clearance of $A \beta$ from brain by functioning as a transporter molecule. Two major pathways govern $A \beta$ clearance. By the first pathway, $A \beta$ is removed from brain to blood via active transport across the BBB. This active transport is performed by specialized transporters, so-called "A $\beta$-receptors", expressed by endothelial cells. Second, $A \beta$ is removed from brain via phagocytosis by both microglial cells and astrocytes. In both pathways, interaction of $A \beta$ with cell surface $A \beta$-receptors is crucial; therefore, the expression levels of $A \beta$-binding proteins might contribute to $A \beta$ clearance by regulating its binding with $\mathrm{A} \beta$ receptors.

The low-density lipoprotein receptor-related protein-1 (LRP-1) binds $\mathrm{A} \beta$ in a complex with ApoE at the abluminal side of the endothelium and internalizes these $A p o E / A \beta$ complexes followed by degradation in lysosomes or transport into the plasma [4, 175]. However, LRP-1 also mediates transport of free $A \beta$ across the BBB [10]. In contrast to LRP-1, the receptor for advanced glycation end products (RAGE) transports $A \beta$ from the circulation into the central nervous system [176]. Similar to RAGE, the $A \beta$ receptor megalin is also involved in the transport of $A \beta$ from blood to brain, although megalin probably plays only a minor role in $A \beta$ transport. Furthermore, megalin binds $A \beta / A p o E$ complexes rather than free $A \beta[177,178]$. Clearance of $A \beta / A p o E$ complexes from brain might be ApoE isoformdependent. ApoE4 forms less stable complexes with $A \beta$ than ApoE3 or ApoE2; therefore, ApoE4 reduces $A \beta$ transport efficiency across the BBB. Additionally, as described above (paragraph 2), ApoE4 enhances $A \beta$ aggregation more efficiently than ApoE3, which also inhibits clearance. On the other hand, the LDL receptor shows a marked preference for the ApoE3 and ApoE4 isoforms and binds the ApoE2 isoform poorly [179]. Given the similarity between the LDL receptor family, other LDL receptors, such as the LRP-1 receptor, might display similar specificities towards the ApoE isoforms, but this has not been reported yet. Moreover, lipidation of ApoE also affects clearance of ApoE and ApoE/A $\beta$ complexes from brain, as LRP 
Table 1 Summary of the expression of chaperones in $\mathrm{AD}$ brains and their interaction and effects on $\mathrm{A} \beta$ and tau

\begin{tabular}{|c|c|c|c|c|}
\hline & SP/CAA & NFT & Direct interaction & Effects on $A \beta$ or tau in general \\
\hline \multicolumn{5}{|l|}{ Apolipoproteins } \\
\hline ApoE & + & + & $A \beta /$ tau & $\uparrow$ Fibrillar $\mathrm{A} \beta / \downarrow$ hyperph. Tau \\
\hline ApoJ & + & $?$ & $\mathrm{~A} \beta$ & $\downarrow \mathrm{A} \beta$ aggregation \\
\hline \multicolumn{5}{|l|}{ HSPGs } \\
\hline Perlecan & \pm & \pm & $A \beta$ & HSPGs: \\
\hline Agrin & + & - & $A \beta$ & $\downarrow$ Proteolytic breakdown $A \beta$ \\
\hline Glypican 1 & + & - & $?$ & $\uparrow$ Non-fibrillar $\rightarrow$ fibrillar $\mathrm{A} \beta$ \\
\hline Syndecan 1-3 & + & - & $?$ & $\uparrow$ Phosphorylation tau \\
\hline Collagen XVIII & + & - & $?$ & \\
\hline GAGs & + & + & $A \beta /$ tau & \\
\hline \multicolumn{5}{|l|}{ Complement factors } \\
\hline Hageman Factor & + & + & $?$ & $\mathrm{~A} \beta$ activates complement in $\mathrm{AD}$ \\
\hline $\mathrm{C} 1 \mathrm{q}$ & + & + & $A \beta$ & $\mathrm{C} 3 \downarrow \mathrm{A} \beta$ deposition \\
\hline $\mathrm{C} 3 / \mathrm{C} 4$ & + & + & $A \beta$ & \\
\hline C5-9 & + & + & $?$ & \\
\hline \multicolumn{5}{|l|}{ Heat shock proteins } \\
\hline Hsp90 & + & $?$ & Tau & $\downarrow$ Tau aggregation \\
\hline Hsp70 & + & $?$ & $A \beta /$ tau & $\downarrow$ Tau aggregation \\
\hline \multicolumn{5}{|l|}{ Small Hsps } \\
\hline$\alpha \mathrm{B}$-crystallin & - & - & $A \beta$ & $\downarrow \mathrm{A} \beta$ fibril formation \\
\hline Hsp27 & - & \pm & $\mathrm{A} \beta / \mathrm{tau}$ & $\downarrow \mathrm{A} \beta$ fibril formation \\
\hline Hsp20 & + & - & $A \beta$ & $\downarrow \mathrm{A} \beta$ fibril formation \\
\hline $\mathrm{HspB} 2 / \mathrm{B} 3$ & + & + & - & No effect \\
\hline HspB8 & + & - & $\mathrm{A} \beta$ & $\downarrow \mathrm{A} \beta$ fibril formation \\
\hline \multicolumn{5}{|l|}{ Acute phase proteins } \\
\hline$\alpha_{1}$-antichymotrypsin & + & - & $\mathrm{A} \beta$ & $\uparrow \mathrm{A} \beta$ fibrillization \\
\hline$\alpha_{2}$-macroglobulin & + & - & $A \beta$ & \\
\hline serum amyloid $\mathrm{P}$ & + & + & $A \beta$ & $\uparrow \mathrm{A} \beta$ fibrillization \\
\hline \multicolumn{5}{|c|}{ Miscellaneous compounds } \\
\hline tPA & - & - & $A \beta$ & $\downarrow \mathrm{A} \beta$ fibril formation \\
\hline Gelsolin & - & - & $\mathrm{A} \beta$ & $\uparrow \mathrm{A} \beta$ fibrillization \\
\hline
\end{tabular}

Expression of chaperones in a specific lesion is illustrated as follows: present (+), by conflicting reports $( \pm)$, absence $(-)$, and unknown (?); $\downarrow=$ inhibition or down-regulation, $\uparrow=$ induction or up-regulation

$S P$ Senile plaques, $C A A$ cerebral amyloid angiopathy, $N F T$ neurofibrillary tangles, $H S P G s$ heparan sulphate proteoglycans, $A \beta$ amyloid-beta, $H s p$ heat shock proteins, Apo apolipoproteins, $S A P$ serum amyloid P, $t P A$ tissue-type plasminogen activator, GAGs glycosaminoglycans, $L D L R$ lowdensity lipoprotein receptor, $L R P-1$ LDL receptor protein-1, $B B B$ blood-brain barrier

preferentially binds lipid-rich forms of ApoE [179]. These data indicate that $\mathrm{A} \beta$-binding proteins, especially ApoE, and possibly, ApoJ, play an important role in transport of $A \beta$ across the BBB and that both the ApoE isoform and the ApoE lipidation state affect $A \beta$ clearance. In addition to $A p o E$ and ApoJ, the $A \beta$-binding protein $\alpha 2 \mathrm{M}$ also forms complexes with $A \beta$. As $\alpha 2 M$ is a ligand for LRP-1, these $\alpha 2 \mathrm{M} / \mathrm{A} \beta$ complexes might undergo LRP-1-mediated endocytosis and degradation or translocation into the plasma [7, 139].

Stimulation of the transport of $\mathrm{A} \beta$ across the $\mathrm{BBB}$ demonstrated to be an effective therapeutic approach in $\mathrm{AD}$, as several studies demonstrated elevated levels of $\mathrm{A} \beta$ in the plasma of mice after passive immunization with anti$\mathrm{A} \beta$ antibodies or Fab fragments [180-182], and decline in cognitive performance was arrested in patients that received vaccination [183]. However, the occurrence of severe meningoencephalitis in human patients after active immu- nization with $A \beta$ hampered widespread application of this type of therapy. Administration of $A \beta$-binding proteins that demonstrate similar positive effects, but possibly, without the severe immune reactions associated with antibody therapy, might provide an alternative strategy. An interesting example of such an $A \beta$-binding protein is gelsolin. This protein has high affinity for $A \beta$ and reduces $A \beta$ levels in a transgenic mouse model of AD [184]. Furthermore, administration of gelsolin or GM1 in PS/APP mice resulted in decreased $A \beta$ aggregation in the brains [184]. Both gelsolin and GM1 act as a "peripheral sink" for $A \beta$. Although both compounds did not enter the brain, they lowered soluble $A \beta$ concentrations in the blood, shifted the balance between blood and cerebral $A \beta$ concentrations, and accordingly, stimulated $A \beta$ transport over the BBB. Therefore, other $A \beta$-binding proteins administered in the circulation might also act as "peripheral sinks" [181, 184]. 
Both activated microglial cells and activated astrocytes are associated with $A \beta$ deposition and may internalize $A \beta$ fragments via phagocytosis [185-187]. Activation of the complement system is, among others, achieved by Hsps such as Hsp60 and Hsp70, which are able to induce phagocytosis by microglia, and thus, clearance of $\mathrm{A} \beta[132$, 188, 189]. In addition, the absence of ApoE reduces internalization and degradation of $A \beta$ by astrocytes in the brain, demonstrating that ApoE is directly involved in the clearance of $\mathrm{A} \beta$ from brain via phagocytosis by microglial cells and astrocytes [40]. tPA might also contribute to clearance of $A \beta$, as it accelerates $A \beta$ clearance from transgenic mouse brains [146]. Thus, as $A \beta$-chaperones contribute to activation of the complement system or activation of microglial cells and astrocytes, these proteins might contribute to the clearance of $A \beta$ from the brain via phagocytosis.

\section{Concluding Remarks}

Professional chaperones, such as the heat shock protein family, and amateur chaperones, such as apolipoproteins and HSPGs and several other proteins, have a role in the intracellular handling of misfolded proteins, induce conformational changes of proteins, or act as transporter of proteins (Fig. 2). This suggests that these chaperones form interesting therapeutic targets in the prevention and treatment of neurodegenerative diseases.

In the process of clearance of $A \beta$ from the brain, $A \beta$ binding partners might play important roles by acting as $\mathrm{A} \beta$ transporter proteins in both the receptor-mediated clearance of $\mathrm{A} \beta$ across the $\mathrm{BBB}$ but also as a "peripheral sink" for $A \beta$. Both ApoE isotype and local concentrations in the brain might regulate $A \beta$ transport across the $B B B$, but as this transport is receptor-mediated, other $A \beta$-binding
Fig. 2 The putative role of chaperones in amyloid- $\beta(A \beta)$ fibril formation, proteolytic breakdown, and clearance from the brain. In Alzheimer's disease, soluble $A \beta$, predominantly produced in neurons, is converted into $\beta$-sheet rich protofibrils and eventually forms mature $A \beta$ fibrils. The conversion from soluble $A \beta$ to protofibrils and fibrils, which accumulate in senile plaques and cerebral amyloid angiopathy, is enhanced by chaperones as apolipoprotein E (ApoE), Gelsolin, $\alpha_{1}$-antichymotrypsin (ACT) and several heparan sulphate proteoglycans (HSPGs), which function as catalysts. In contrast, the heat shock protein family, tissue-type plasminogen activator (tPA) and complement factors prevent the transition of soluble $A \beta$ into protofibrils and mature fibrils. Furthermore, heat shock proteins and tPA stimulate the proteolytic breakdown of (proto) fibrils, whereas HSPGs prevent this breakdown. Finally, the clearance of $\mathrm{A} \beta$ from the brain across the blood-brain barrier is stimulated by ApoE, ApoJ, and $\alpha_{2}$-macroglobulin $(\alpha 2 \mathrm{M})$, whereas complement factors stimulate phagocytosis-mediated clearance of $A \beta$ by activated microglia and astrocytes

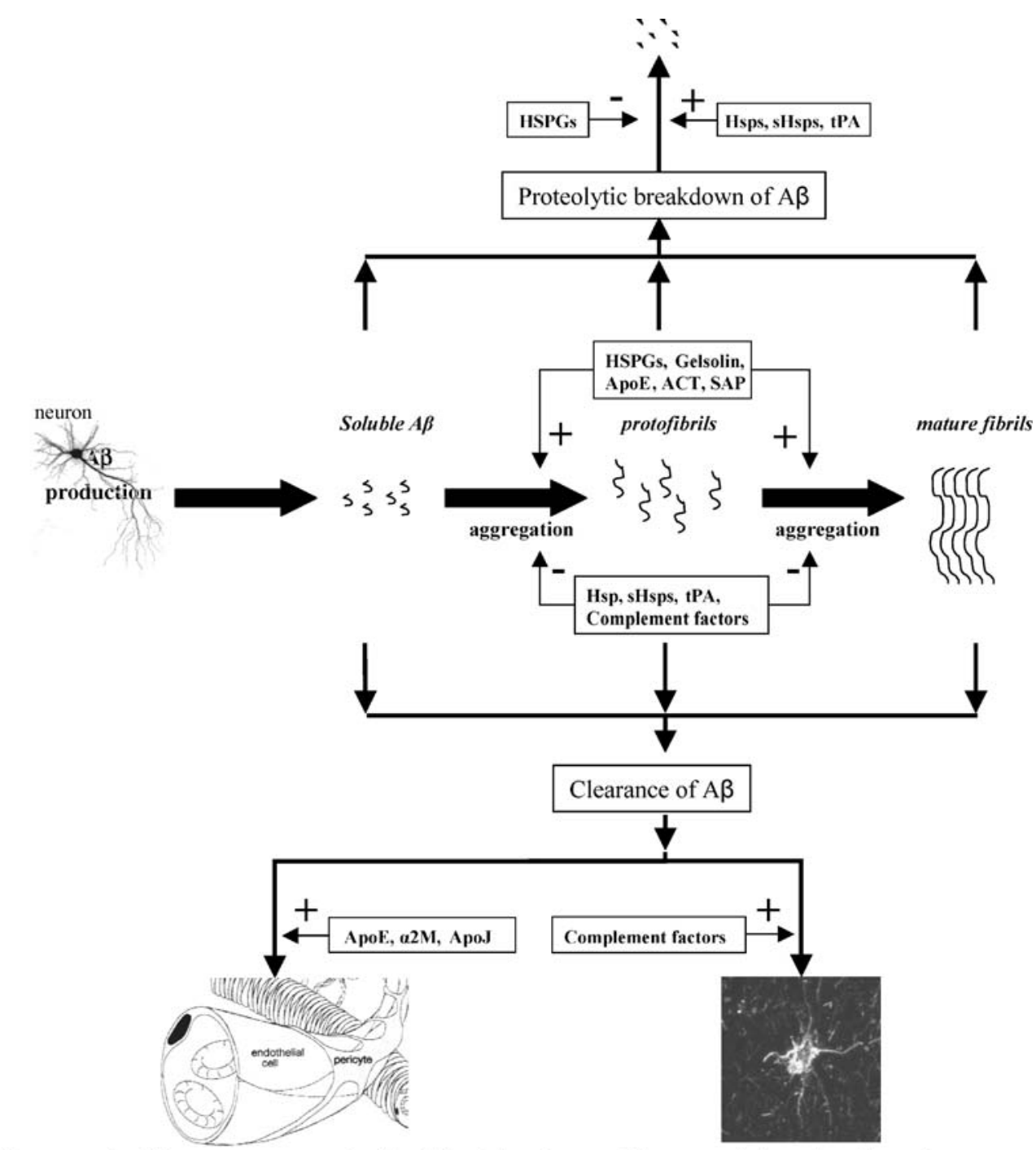

Transport via $\mathrm{A} \beta$-receptors across the blood-brain barrier
Phagocytosis by microglia and astrocytes 
proteins might also fulfill such a role. In addition, transport of aggregated $A \beta$ across the BBB is less efficient than soluble $A \beta$. Thus, by preventing self-aggregation of $A \beta$, $A \beta$-binding proteins contribute to the clearance of $A \beta$ from the brain. As a therapeutic strategy, $A \beta$-binding proteins serving as a "peripheral sink", such as gelsolin, seem promising [184].

Overexpression of professional chaperones, such as the Hsps, to prevent aggregation of misfolded proteins will have to be evaluated carefully, as they also interact with other chaperones and are dependent on this interaction to fulfill some of their functions. This strategy may therefore result in instability of the cell-stress mechanism, which may cause the system to collapse. A solution may be found in the overexpression of several chaperones, which may be required to achieve an impact on the progression of the disease.

Another pitfall in the use of professional chaperones as therapeutic agents is their ability to bind misfolded proteins and keep them in an intermediate conformation. This type of conformation might even be more toxic than the aggregated state. As an example, co-incubations of $\alpha \mathrm{B}$-cystallin with $\mathrm{A} \beta$ are more toxic to neurons than $A \beta$ alone [121]. Furthermore, Hsps are most likely to be involved in early development of neurodegenerative diseases, given their natural function. Yet, the role of this protein family in maturation of the neurodegenerative lesions remains to be elucidated.

In conclusion, studying the role of chaperones, both professional and amateur, in the pathophysiology of $\mathrm{AD}$ will provide us with a better understanding of the mechanisms underlying the formation and accumulation of toxic aggregates in AD, which, eventually, will lead to the design of more effective therapeutic strategies.

\begin{abstract}
Acknowledgments This work was supported by grants from the "Internationale Stichting Alzheimer Onderzoek" (ISAO, grants 01506 and 03517), Zon-MW Innovational Research (number 917.46.331, "Vidi program") and the "Hersenstichting Nederland" (number 11F03 (2) 11 and 14F06.18). We would like to thank Wilbert Boelens for helpful discussions.
\end{abstract}

\section{References}

1. Selkoe DJ (1991) The molecular pathology of Alzheimer's disease. Neuron 6:487-498

2. Glenner GG, Wong CW (1984) Alzheimer's disease: initial report of the purification and characterization of a novel cerebrovascular amyloid protein. Biochem Biophys Res Commun 120:885-890

3. Lee VM, Balin BJ, Otvos L, Jr, Trojanowski JQ (1991) A68: a major subunit of paired helical filaments and derivatized forms of normal tau. Science 251:675-678

4. Zlokovic BV (2004) Clearing amyloid through the blood-brain barrier. J Neurochem 89:807-811
5. Nagele RG, D'Andrea MR, Lee H, Venkataraman V, Wang HY (2003) Astrocytes accumulate A beta 42 and give rise to astrocytic amyloid plaques in Alzheimer disease brains. Brain Res 971:197-209

6. Paresce DM, Ghosh RN, Maxfield FR (1996) Microglial cells internalize aggregates of the Alzheimer's disease amyloid betaprotein via a scavenger receptor. Neuron 17:553-565

7. Tanzi RE, Moir RD, Wagner SL (2004) Clearance of Alzheimer's Abeta peptide: the many roads to perdition. Neuron 43:605-608

8. Selkoe DJ (1997) Alzheimer's disease: genotypes, phenotypes, and treatments. Science 275:630-631

9. Selkoe DJ (2000) The origins of Alzheimer disease: a is for amyloid. JAMA 283:1615-1617

10. Deane R, Wu Z, Sagare A, Davis J, Du YS, Hamm K, Xu F, Parisi M, LaRue B, Hu HW, Spijkers P, Guo H, Song X, Lenting PJ, Van Nostrand WE, Zlokovic BV (2004) LRP/amyloid betapeptide interaction mediates differential brain efflux of Abeta isoforms. Neuron 43:333-344

11. Dickson DW (1997) The pathogenesis of senile plaques. J Neuropathol ExpNeurol 56:321-339

12. Rogers J, Cooper NR, Webster S, Schultz J, McGeer PL, Styren SD, Civin WH, Brachova L, Bradt B, Ward P (1992) Complement activation by beta-amyloid in Alzheimer disease. Proc Natl Acad Sci USA 89:10016-10020

13. Rogers J, Lue LF (2001) Microglial chemotaxis, activation, and phagocytosis of amyloid beta-peptide as linked phenomena in Alzheimer's disease. Neurochem Int 39:333-340

14. Boyles JK, Pitas RE, Wilson E, Mahley RW, Taylor JM (1985) Apolipoprotein E associated with astrocytic glia of the central nervous system and with nonmyelinating glia of the peripheral nervous system. J Clin Invest 76:1501-1513

15. Pitas RE, Boyles JK, Lee SH, Foss D, Mahley RW (1987) Astrocytes synthesize apolipoprotein E and metabolize apolipoprotein E-containing lipoproteins. Biochim Biophys Acta 917:148-161

16. Pitas RE, Boyles JK, Lee SH, Hui D, Weisgraber KH (1987) Lipoproteins and their receptors in the central nervous system. Characterization of the lipoproteins in cerebrospinal fluid and identification of apolipoprotein $\mathrm{B}, \mathrm{E}(\mathrm{LDL})$ receptors in the brain. J Biol Chem 262:14352-14360

17. Stone DJ, Rozovsky I, Morgan TE, Anderson CP, Hajian H, Finch CE (1997) Astrocytes and microglia respond to estrogen with increased apoE mRNA in vivo and in vitro. Exp Neurol 143:313-318

18. Wilhelmus MM, Otte-Holler I, Davis J, Van Nostrand WE, de Waal RM, Verbeek MM (2005) Apolipoprotein E genotype regulates amyloid-beta cytotoxicity. J Neurosci 25:3621-3627

19. Mahley RW (1988) Apolipoprotein E: cholesterol transport protein with expanding role in cell biology. Science 240:622-630

20. Plump AS, Breslow JL (1995) Apolipoprotein E and the apolipoprotein E-deficient mouse. Annu Rev Nutr 15:495-518

21. Corder EH, Saunders AM, Strittmatter WJ, Schmechel DE, Gaskell PC, Small GW, Roses AD, Haines JL, Pericak-Vance MA (1993) Gene dose of apolipoprotein E type 4 allele and the risk of Alzheimer's disease in late onset families. Science 261:921-923

22. Corder EH, Saunders AM, Risch NJ, Strittmatter WJ, Schmechel DE, Gaskell PC Jr, Rimmler JB, Locke PA, Conneally PM, Schmader KE (1994) Protective effect of apolipoprotein E type 2 allele for late onset Alzheimer disease. Nat Genet 7:180-184

23. Mayeux R, Stern Y, Ottman R, Tatemichi TK, Tang MX, Maestre G, Ngai C, Tycko B, Ginsberg H (1993) The apolipoprotein epsilon 4 allele in patients with Alzheimer's disease. Ann Neurol 34:752754

24. Strittmatter WJ, Roses AD (1996) Apolipoprotein E and Alzheimer's disease. Annu Rev Neurosci 19:53-77

25. Namba Y, Tomonaga M, Kawasaki H, Otomo E, Ikeda K (1991) Apolipoprotein E immunoreactivity in cerebral amyloid deposits 
and neurofibrillary tangles in Alzheimer's disease and kuru plaque amyloid in Creutzfeldt-Jakob disease. Brain Res 541:163-166

26. Wisniewski T, Frangione B (1992) Apolipoprotein E: a pathological chaperone protein in patients with cerebral and systemic amyloid. Neurosci Lett 135:235-238

27. Strittmatter WJ, Saunders AM, Schmechel D, Pericak-Vance M, Enghild J, Salvesen GS, Roses AD (1993) Apolipoprotein E: high-avidity binding to beta-amyloid and increased frequency of type 4 allele in late-onset familial Alzheimer disease. Proc Natl Acad Sci USA 90:1977-1981

28. Strittmatter WJ, Weisgraber KH, Huang DY, Dong LM, Salvesen GS, Pericak-Vance M, Schmechel D, Saunders AM, Goldgaber D, Roses AD (1993) Binding of human apolipoprotein $E$ to synthetic amyloid beta peptide: isoform-specific effects and implications for late-onset Alzheimer disease. Proc Natl Acad Sci USA 90:80988102

29. LaDu MJ, Falduto MT, Manelli AM, Reardon CA, Getz GS, Frail DE (1994) Isoform-specific binding of apolipoprotein $E$ to beta-amyloid. J Biol Chem 269:23403-23406

30. Strittmatter WJ, Weisgraber KH, Huang DY, Dong LM, Salvesen GS, Pericak-Vance M, Schmechel D, Saunders AM, Goldgaber D, Roses AD (1993) Binding of human apolipoprotein E to synthetic amyloid beta peptide: isoform-specific effects and implications for late-onset Alzheimer disease. Proc Natl Acad Sci USA 90:80988102

31. Bales KR, Verina T, Dodel RC, Du Y, Altstiel L, Bender M, Hyslop P, Johnstone EM, Little SP, Cummins DJ, Piccardo P, Ghetti B, Paul SM (1997) Lack of apolipoprotein E dramatically reduces amyloid beta-peptide deposition. Nat Genet 17:263-264

32. Bales KR, Verina T, Cummins DJ, Du Y, Dodel RC, Saura J, Fishman CE, DeLong CA, Piccardo P, Petegnief V, Ghetti B., Paul S.M. (1999) Apolipoprotein E is essential for amyloid deposition in the APP(V717F) transgenic mouse model of Alzheimer's disease. Proc Natl Acad Sci USA 96:15233-15238

33. Dolev I, Michaelson DM (2004) A nontransgenic mouse model shows inducible amyloid-beta (Abeta) peptide deposition and elucidates the role of apolipoprotein $\mathrm{E}$ in the amyloid cascade. Proc Natl Acad Sci USA 101:13909-13914

34. Fryer JD, Taylor JW, DeMattos RB, Bales KR, Paul SM, Parsadanian M, Holtzman DM (2003) Apolipoprotein E markedly facilitates age-dependent cerebral amyloid angiopathy and spontaneous hemorrhage in amyloid precursor protein transgenic mice. $\mathrm{J}$ Neurosci 23:7889-7896

35. Sadowski M, Pankiewicz J, Scholtzova H, Ripellino JA, Li Y, Schmidt SD, Mathews PM, Fryer JD, Holtzman DM, Sigurdsson EM, Wisniewski T (2004) A synthetic peptide blocking the apolipoprotein E/beta-amyloid binding mitigates beta-amyloid toxicity and fibril formation in vitro and reduces beta-amyloid plaques in transgenic mice. Am J Pathol 165:937-948

36. Holtzman DM, Bales KR, Wu S, Bhat P, Parsadanian M, Fagan AM, Chang LK, Sun Y, Paul SM (1999) Expression of human apolipoprotein $\mathrm{E}$ reduces amyloid-beta deposition in a mouse model of Alzheimer's disease. J Clin Invest 103:R15-R21

37. Holtzman DM, Bales KR, Tenkova T, Fagan AM, Parsadanian M, Sartorius LJ, Mackey B, Olney J, McKeel D, Wozniak D, Paul SM (2000) Apolipoprotein E isoform-dependent amyloid deposition and neuritic degeneration in a mouse model of Alzheimer's disease. Proc Natl Acad Sci USA 97:2892-2897

38. Carter DB, Dunn E, McKinley DD, Stratman NC, Boyle TP, Kuiper SL, Oostveen JA, Weaver RJ, Boller JA, Gurney ME (2001) Human apolipoprotein E4 accelerates beta-amyloid deposition in APPsw transgenic mouse brain. Ann Neurol $50 \cdot 468-475$

39. Fryer JD, DeMattos RB, McCormick LM, O'Dell MA, Spinner ML, Bales KR, Paul SM, Sullivan PM, Parsadanian M, Bu G,
Holtzman DM (2005) The low density lipoprotein receptor regulates the level of central nervous system human and murine apolipoprotein E but does not modify amyloid plaque pathology in PDAPP mice. J Biol Chem 280:25754-25759

40. Koistinaho M, Lin S, Wu X, Esterman M, Koger D, Hanson J, Higgs R, Liu F, Malkani S, Bales KR, Paul SM (2004) Apolipoprotein E promotes astrocyte colocalization and degradation of deposited amyloid-beta peptides. Nat Med 10:719 726

41. Strittmatter WJ, Weisgraber KH, Goedert M, Saunders AM, Huang D, Corder EH, Dong LM, Jakes R, Alberts MJ, Gilbert JR (1994) Hypothesis: microtubule instability and paired helical filament formation in the Alzheimer disease brain are related to apolipoprotein E genotype. Exp Neurol 125:163-171

42. Strittmatter WJ, Saunders AM, Goedert M, Weisgraber KH, Dong LM, Jakes R, Huang DY, Pericak-Vance M, Schmechel D, Roses AD (1994) Isoform-specific interactions of apolipoprotein $\mathrm{E}$ with microtubule-associated protein tau: implications for Alzheimer disease. Proc Natl Acad Sci USA 91:1118311186

43. Ghebremedhin E, Schultz C, Braak E, Braak H (1998) High frequency of apolipoprotein E epsilon4 allele in young individuals with very mild Alzheimer's disease-related neurofibrillary changes. Exp Neurol 153:152-155

44. Ohm TG, Scharnagl H, Marz W, Bohl J (1999) Apolipoprotein E isoforms and the development of low and high Braak stages of Alzheimer's disease-related lesions. Acta Neuropathol (Berl) 98:273-280

45. Tesseur I, Van Dorpe J, Spittaels K, Van den HC, Moechars D, Van Leuven F (2000) Expression of human apolipoprotein E4 in neurons causes hyperphosphorylation of protein tau in the brains of transgenic mice. Am J Pathol 156:951-964

46. Yasojima K, Schwab C, McGeer EG, McGeer PL (1999) Upregulated production and activation of the complement system in Alzheimer's disease brain. Am J Pathol 154:927-936

47. Barger SW, Harmon AD (1997) Microglial activation by Alzheimer amyloid precursor protein and modulation by apolipoprotein E. Nature 388:878-881

48. $\mathrm{Hu}$ J, LaDu MJ, Van Eldik LJ (1998) Apolipoprotein E attenuates beta-amyloid-induced astrocyte activation. J Neurochem 71:1626-1634

49. Laskowitz DT, Goel S, Bennett ER, Matthew WD (1997) Apolipoprotein E suppresses glial cell secretion of TNF alpha. J Neuroimmunol 76:70-74

50. Laskowitz DT, Lee DM, Schmechel D, Staats HF (2000) Altered immune responses in apolipoprotein E-deficient mice. J Lipid Res 41:613-620

51. Lynch JR, Morgan D, Mance J, Matthew WD, Laskowitz DT (2001) Apolipoprotein E modulates glial activation and the endogenous central nervous system inflammatory response. J Neuroimmunol 114:107-113

52. Colton CA, Brown CM, Czapiga M, Vitek MP (2002) Apolipoprotein-E allele-specific regulation of nitric oxide production. Ann N Y Acad Sci 962:212-225

53. Trougakos IP, Gonos ES (2002) Clusterin/apolipoprotein $\mathrm{J}$ in human aging and cancer. Int J Biochem Cell Biol 34:1430-1448

54. Calero M, Rostagno A, Matsubara E, Zlokovic B, Frangione B, Ghiso J (2000) Apolipoprotein J (clusterin) and Alzheimer's disease. Microsc Res Tech 50:305-315

55. Rosenberg ME, Dvergsten J, Correa-Rotter R (1993) Clusterin: an enigmatic protein recruited by diverse stimuli. J Lab Clin Med 121:205-214

56. Zlokovic BV, Martel CL, Mackic JB, Matsubara E, Wisniewski T, McComb JG, Frangione B, Ghiso J (1994) Brain uptake of circulating apolipoproteins $\mathrm{J}$ and E complexed to Alzheimer's amyloid beta. Biochem Biophys Res Commun 205:1431-1437 
57. Rassart E, Bedirian A, Do CS, Guinard O, Sirois J, Terrisse L, Milne R (2000) Apolipoprotein D. Biochim Biophys Acta 1482:185-198

58. Belloir B, Kovari E, Surini-Demiri M, Savioz A (2001) Altered apolipoprotein D expression in the brain of patients with Alzheimer disease. J Neurosci Res 64:61-69

59. Terrisse L, Seguin D, Bertrand P, Poirier J, Milne R, Rassart E (1999) Modulation of apolipoprotein D and apolipoprotein E expression in rat hippocampus after entorhinal cortex lesion. Brain Res Mol Brain Res 70:26-35

60. Bernfield M, Gotte M, Park PW, Reizes O, Fitzgerald ML, Lincecum J, Zako M (1999) Functions of cell surface heparan sulfate proteoglycans. Annu Rev Biochem 68:729-777

61. van Horssen J, Wesseling P, van den Heuvel LP, de Waal RM, Verbeek MM (2003) Heparan sulphate proteoglycans in Alzheimer's disease and amyloid-related disorders. Lancet Neurol 2:482-492

62. Iozzo RV (2001) Heparan sulfate proteoglycans: intricate molecules with intriguing functions. J Clin Invest 108:165-167

63. Perry G, Siedlak SL, Richey P, Kawai M, Cras P, Kalaria RN, Galloway PG, Scardina JM, Cordell B, Greenberg BD (1991) Association of heparan sulfate proteoglycan with the neurofibrillary tangles of Alzheimer's disease. J Neurosci 11:3679-3683

64. Snow AD, Mar H, Nochlin D, Kimata K, Kato M, Suzuki S, Hassell J, Wight TN (1988) The presence of heparan sulfate proteoglycans in the neuritic plaques and congophilic angiopathy in Alzheimer's disease. Am J Pathol 133:456-463

65. Snow AD, Mar H, Nochlin D, Sekiguchi RT, Kimata K, Koike Y, Wight TN (1990) Early accumulation of heparan sulfate in neurons and in the beta-amyloid protein-containing lesions of Alzheimer's disease and Down's syndrome. Am J Pathol 137:1253-1270

66. Snow AD, Sekiguchi RT, Nochlin D, Kalaria RN, Kimata K (1994) Heparan sulfate proteoglycan in diffuse plaques of hippocampus but not of cerebellum in Alzheimer's disease brain. Am J Pathol 144:337-347

67. Snow AD, Kinsella MG, Parks E, Sekiguchi RT, Miller JD, Kimata K, Wight TN (1995) Differential binding of vascular cell-derived proteoglycans (perlecan, biglycan, decorin, and versican) to the beta-amyloid protein of Alzheimer's disease. Arch Biochem Biophys 320:84-95

68. van Horssen J, Otte-Holler I, David G, Maat-Schieman ML, van den Heuvel LP, Wesseling P, de Waal RM, Verbeek MM (2001) Heparan sulfate proteoglycan expression in cerebrovascular amyloid beta deposits in Alzheimer's disease and hereditary cerebral hemorrhage with amyloidosis (Dutch) brains. Acta Neuropathol (Berl) 102:604-614

69. Verbeek MM, Otte-Holler I, van den BJ, van den Heuvel LP, David G, Wesseling P, de Waal RM (1999) Agrin is a major heparan sulfate proteoglycan accumulating in Alzheimer's disease brain. Am J Pathol 155:2115-2125

70. Cotman SL, Halfter W, Cole GJ (2000) Agrin binds to betaamyloid (Abeta), accelerates abeta fibril formation, and is localized to Abeta deposits in Alzheimer's disease brain. Mol Cell Neurosci 15:183-198

71. Donahue JE, Berzin TM, Rafii MS, Glass DJ, Yancopoulos GD, Fallon JR, Stopa EG (1999) Agrin in Alzheimer's disease: altered solubility and abnormal distribution within microvasculature and brain parenchyma. Proc Natl Acad Sci USA 96:6468-6472

72. van Horssen J, Wilhelmus MM, Heljasvaara R, Pihlajaniemi T, Wesseling P, de Waal RM, Verbeek MM (2002) Collagen XVIII: a novel heparan sulfate proteoglycan associated with vascular amyloid depositions and senile plaques in Alzheimer's disease brains. Brain Pathol 12:456-462

73. Gupta-Bansal R, Frederickson RC, Brunden KR (1995) Proteoglycan-mediated inhibition of A beta proteolysis. A potential cause of senile plaque accumulation. J Biol Chem 270:1866618671

74. Castillo GM, Ngo C, Cummings J, Wight TN, Snow AD (1997) Perlecan binds to the beta-amyloid proteins (A beta) of Alzheimer's disease, accelerates A beta fibril formation, and maintains A beta fibril stability. J Neurochem 69:2452-2465

75. Snow AD, Sekiguchi R, Nochlin D, Fraser P, Kimata K, Mizutani A, Arai M, Schreier WA, Morgan DG (1994) An important role of heparan sulfate proteoglycan (Perlecan) in a model system for the deposition and persistence of fibrillar A beta-amyloid in rat brain. Neuron 12:219-234

76. Verbeek MM, Eikelenboom P, de Waal RM (1997) Differences between the pathogenesis of senile plaques and congophilic angiopathy in Alzheimer disease. J Neuropathol Exp Neurol 56:751-761

77. Buee L, Ding W, Anderson JP, Narindrasorasak S, Kisilevsky R, Boyle NJ, Robakis NK, Delacourte A, Greenberg B, Fillit HM (1993) Binding of vascular heparan sulfate proteoglycan to Alzheimer's amyloid precursor protein is mediated in part by the N-terminal region of A4 peptide. Brain Res 627:199-204

78. Narindrasorasak S, Lowery D, Gonzalez-DeWhitt P, Poorman RA, Greenberg B, Kisilevsky R (1991) High affinity interactions between the Alzheimer's beta-amyloid precursor proteins and the basement membrane form of heparan sulfate proteoglycan. J Biol Chem 266:12878-12883

79. Snow AD, Willmer JP, Kisilevsky R (1987) Sulfated glycosaminoglycans in Alzheimer's disease. Hum Pathol 18:506-510

80. Goedert M, Jakes R, Spillantini MG, Hasegawa M, Smith MJ, Crowther RA (1996) Assembly of microtubule-associated protein tau into Alzheimer-like filaments induced by sulphated glycosaminoglycans. Nature 383:550-553

81. Gervais F, Chalifour R, Garceau D, Kong X, Laurin J, Mclaughlin R, Morissette C, Paquette J (2001) Glycosaminoglycan mimetics: a therapeutic approach to cerebral amyloid angiopathy. Amyloid 8 Suppl 1:28-35

82. Zhu H, Yu J, Kindy MS (2001) Inhibition of amyloidosis using low-molecular-weight heparins. Mol Med 7:517-522

83. Kisilevsky R, Lemieux LJ, Fraser PE, Kong X, Hultin PG, Szarek WA (1995) Arresting amyloidosis in vivo using smallmolecule anionic sulphonates or sulphates: implications for Alzheimer's disease. Nat Med 1:143-148

84. Banz Y, Hess OM, Robson SC, Mettler D, Meier P, Haeberli A, Csizmadia E, Korchagina EY, Bovin NV, Rieben R (2005) Locally targeted cytoprotection with dextran sulfate attenuates experimental porcine myocardial ischaemia/reperfusion injury. Eur Heart J 26:2334-2343

85. Kirschfink M, Blase L, Engelmann S, Schwartz-Albiez R (1997) Secreted chondroitin sulfate proteoglycan of human B cell lines binds to the complement protein $\mathrm{Clq}$ and inhibits complex formation of C1. J Immunol 158:1324-1331

86. Caughman GB, Boackle RJ, Vesely J (1982) A postulated mechanism for heparin's potentiation of $\mathrm{C} 1$ inhibitor function. Mol Immunol 19:287-295

87. Eikelenboom P, Stam FC (1982) Immunoglobulins and complement factors in senile plaques. An immunoperoxidase study. Acta Neuropathol (Berl) 57:239-242

88. Eikelenboom P, Stam FC (1984) An immunohistochemical study on cerebral vascular and senile plaque amyloid in Alzheimer's dementia. Virchows Arch B Cell Pathol Incl Mol Pathol 47:1725

89. McGeer PL, Akiyama H, Itagaki S, McGeer EG (1989) Activation of the classical complement pathway in brain tissue of Alzheimer patients. Neurosci Lett 107:341-346

90. Webster S, Bradt B, Rogers J, Cooper N (1997) Aggregation state-dependent activation of the classical complement pathway by the amyloid beta peptide. J Neurochem 69:388-398 
91. Webster S, Lue LF, Brachova L, Tenner AJ, McGeer PL, Terai K, Walker DG, Bradt B, Cooper NR, Rogers J (1997) Molecular and cellular characterization of the membrane attack complex, C5b-9, in Alzheimer's disease. Neurobiol Aging $18: 415-421$

92. Yasuhara O, Walker DG, McGeer PL (1994) Hageman factor and its binding sites are present in senile plaques of Alzheimer's disease. Brain Res 654:234-240

93. Rozemuller AJ, Eikelenboom P, Theeuwes JW, Jansen Steur EN, de Vos RA (2000) Activated microglial cells and complement factors are unrelated to cortical Lewy bodies. Acta Neuropathol (Berl) 100:701-708

94. Chen S, Frederickson RC, Brunden KR (1996) Neuroglialmediated immunoinflammatory responses in Alzheimer's disease: complement activation and therapeutic approaches. Neurobiol Aging 17:781-787

95. Veerhuis R, Janssen I, Hoozemans JJ, De Groot CJ, Hack CE, Eikelenboom P (1998) Complement C1-inhibitor expression in Alzheimer's disease. Acta Neuropathol (Berl) 96:287-296

96. Walker DG, Yasuhara O, Patston PA, McGeer EG, McGeer PL (1995) Complement C1 inhibitor is produced by brain tissue and is cleaved in Alzheimer disease. Brain Res 675:75-82

97. Wyss-Coray T, Yan F, Lin AH, Lambris JD, Alexander JJ, Quigg RJ, Masliah E (2002) Prominent neurodegeneration and increased plaque formation in complement-inhibited Alzheimer's mice. Proc Natl Acad Sci USA 99:10837-10842

98. Abraham CR (2001) Reactive astrocytes and alpha1-antichymotrypsin in Alzheimer's disease. Neurobiol Aging 22:931-936

99. Gasque P, Dean YD, McGreal EP, VanBeek J, Morgan BP (2000) Complement components of the innate immune system in health and disease in the CNS. Immunopharmacology 49:171-186

100. Wyss-Coray T, Mucke L (2002) Inflammation in neurodegenerative disease - a double-edged sword. Neuron 35:419-432

101. Jiang H, Burdick D, Glabe CG, Cotman CW, Tenner AJ (1994) Beta-amyloid activates complement by binding to a specific region of the collagen-like domain of the $\mathrm{C} 1 \mathrm{q}$ A chain. $\mathrm{J}$ Immunol 152:5050-5059

102. Webster S, Bonnell B, Rogers J (1997) Charge-based binding of complement component $\mathrm{Clq}$ to the Alzheimer amyloid betapeptide. Am J Pathol 150:1531-1536

103. Bitting L, Naidu A, Cordell B, Murphy GM, Jr (1996) Betaamyloid peptide secretion by a microglial cell line is induced by beta-amyloid-(25-35) and lipopolysaccharide. J Biol Chem 271:16084-16089

104. Veerhuis R, Van Breemen MJ, Hoozemans JM, Morbin M, Ouladhadj J, Tagliavini F, Eikelenboom P (2003) Amyloid beta plaque-associated proteins $\mathrm{C} 1 \mathrm{q}$ and SAP enhance the Abeta1-42 peptide-induced cytokine secretion by adult human microglia in vitro. Acta Neuropathol (Berl) 105:135-144

105. Walter S, Buchner J (2002) Molecular chaperones-cellular machines for protein folding. Angew Chem Int Ed Engl 41:1098-1113

106. Gusev NB, Bogatcheva NV, Marston SB (2002) Structure and properties of small heat shock proteins (sHsp) and their interaction with cytoskeleton proteins. Biochemistry (Mosc) 67:511-519

107. MacRae TH (2000) Structure and function of small heat shock/ alpha-crystallin proteins: established concepts and emerging ideas. Cell Mol Life Sci 57:899-913

108. Buchner J (1996) Supervising the fold: functional principles of molecular chaperones. FASEB J 10:10-19

109. de Jong WW, Caspers GJ, Leunissen JA (1998) Genealogy of the alpha-crystallin-small heat-shock protein superfamily. Int J Biol Macromol 22:151-162

110. Kappe G, Franck E, Verschuure P, Boelens WC, Leunissen JA, de Jong WW (2003) The human genome encodes 10 alpha- crystallin-related small heat shock proteins: HspB1-10. Cell Stress Chaperones 8:53-61

111. Iwaki T, Wisniewski T, Iwaki A, Corbin E, Tomokane N, Tateishi J, Goldman JE (1992) Accumulation of alpha B-crystallin in central nervous system glia and neurons in pathologic conditions. Am J Pathol 140:345-356

112. Renkawek K, Voorter CE, Bosman GJ, van Workum FP, de Jong WW (1994) Expression of alpha B-crystallin in Alzheimer's disease. Acta Neuropathol (Berl) 87:155-160

113. Renkawek K, Bosman GJ, de Jong WW (1994) Expression of small heat-shock protein hsp 27 in reactive gliosis in Alzheimer disease and other types of dementia. Acta Neuropathol (Berl) 87:511-519

114. Shinohara H, Inaguma Y, Goto S, Inagaki T, Kato K (1993) Alpha B crystallin and HSP28 are enhanced in the cerebral cortex of patients with Alzheimer's disease. J Neurol Sci 119:203-208

115. Wilhelmus MM, Otte-Holler I, Wesseling P, de Waal RM, Boelens WC, Verbeek MM (2006) Specific association of small heat shock proteins with the pathological hallmarks of Alzheimer's disease brains. Neuropathol Appl Neurobiol 32:119-130

116. Wilhelmus MM, Boelens WC, Otte-Holler I, Kamps B, Kusters B, Maat-Schieman ML, de Waal RM, Verbeek MM (2006) Small heat shock protein HspB8: its distribution in Alzheimer's disease brains and its inhibition of amyloid-beta protein aggregation and cerebrovascular amyloid-beta toxicity. Acta Neuropathol (Berl) 111:139-149

117. Wilhelmus MM, Boelens WC, Otte-Holler I, Kamps B, de Waal RM, Verbeek MM (2006) Small heat shock proteins inhibit amyloid-beta protein aggregation and cerebrovascular amyloidbeta protein toxicity. Brain Res 1089:67-78

118. Kudva YC, Hiddinga HJ, Butler PC, Mueske CS, Eberhardt NL (1997) Small heat shock proteins inhibit in vitro A beta(1-42) amyloidogenesis. FEBS Lett 416:117-121

119. Liang JJ (2000) Interaction between beta-amyloid and lens alphaB-crystallin. FEBS Lett 484:98-101

120. Goldstein LE, Muffat JA, Cherny RA, Moir RD, Ericsson MH, Huang X, Mavros C, Coccia JA, Faget KY, Fitch KA, Masters CL, Tanzi RE, Chylack LT, Bush AI (2003) Cytosolic betaamyloid deposition and supranuclear cataracts in lenses from people with Alzheimer's disease. Lancet 361:1258-1265

121. Stege GJ, Renkawek K, Overkamp PS, Verschuure P, van Rijk AF, Reijnen-Aalbers A, Boelens WC, Bosman GJ, de Jong WW (1999) The molecular chaperone alphaB-crystallin enhances amyloid beta neurotoxicity. Biochem Biophys Res Commun 262:152-156

122. Shimura H, Miura-Shimura Y, Kosik KS (2004) Binding of tau to heat shock protein 27 leads to decreased concentration of hyperphosphorylated tau and enhanced cell survival. J Biol Chem 279:17957-17962

123. Auluck PK, Chan HY, Trojanowski JQ, Lee VM, Bonini NM (2002) Chaperone suppression of alpha-synuclein toxicity in a Drosophila model for Parkinson's disease. Science 295:865-868

124. McLean PJ, Kawamata H, Shariff S, Hewett J, Sharma N, Ueda K, Breakefield XO, Hyman BT (2002) TorsinA and heat shock proteins act as molecular chaperones: suppression of alphasynuclein aggregation. J Neurochem 83:846-854

125. Renkawek K, de Jong WW, Merck KB, Frenken CW, van Workum FP, Bosman GJ (1992) alpha B-crystallin is present in reactive glia in Creutzfeldt-Jakob disease. Acta Neuropathol (Berl) 83:324-327

126. Renkawek K, Bosman GJ, Gaestel M (1993) Increased expression of heat-shock protein $27 \mathrm{kDa}$ in Alzheimer disease: a preliminary study. Neuroreport 5:14-16

127. Nardai G, Csermely P, Soti C (2002) Chaperone function and chaperone overload in the aged. A preliminary analysis. Exp Gerontol 37:1257-1262 
128. Csermely P (2001) Chaperone overload is a possible contributor to 'civilization diseases'. Trends Genet 17:701-704

129. Abraham CR, Shirahama T, Potter H (1990) Alpha 1-antichymotrypsin is associated solely with amyloid deposits containing the beta-protein. Amyloid and cell localization of alpha 1-antichymotrypsin. Neurobiol Aging 11:123-129

130. Bauer J, Strauss S, Schreiter-Gasser U, Ganter U, Schlegel P, Witt I, Yolk B, Berger M (1991) Interleukin-6 and alpha-2-macroglobulin indicate an acute-phase state in Alzheimer's disease cortices. FEBS Lett 285:111-114

131. Holm NE, Nybo M, Junker K, Toftedal HP, Rasmussen IM, Svehag SE (2000) Localization of human serum amyloid $\mathrm{P}$ component and heparan sulfate proteoglycan in in vitro-formed Abeta fibrils. Scand J Immunol 52:110-112

132. Prohaszka Z, Singh M, Nagy K, Kiss E, Lakos G, Duba J, Fust $\mathrm{G}$ (2002) Heat shock protein 70 is a potent activator of the human complement system. Cell Stress Chaperones 7:17-22

133. Licastro F, Mallory M, Hansen LA, Masliah E (1998) Increased levels of alpha-1-antichymotrypsin in brains of patients with Alzheimer's disease correlate with activated astrocytes and are affected by APOE 4 genotype. J Neuroimmunol 88:105-110

134. Eriksson S, Janciauskiene S, Lannfelt L (1995) Alpha 1antichymotrypsin regulates Alzheimer beta-amyloid peptide fibril formation. Proc Natl Acad Sci USA 92:2313-2317

135. Ma J, Yee A, Brewer HB, Jr, Das S, Potter H (1994) Amyloidassociated proteins alpha 1-antichymotrypsin and apolipoprotein E promote assembly of Alzheimer beta-protein into filaments. Nature 372:92-94

136. Du Y, Bales KR, Dodel RC, Liu X, Glinn MA, Horn JW, Little SP, Paul SM (1998) Alpha2-macroglobulin attenuates betaamyloid peptide 1-40 fibril formation and associated neurotoxicity of cultured fetal rat cortical neurons. J Neurochem 70:1182-1188

137. Hughes SR, Khorkova O, Goyal S, Knaeblein J, Heroux J, Riedel NG, Sahasrabudhe S (1998) Alpha2-macroglobulin associates with beta-amyloid peptide and prevents fibril formation. Proc Natl Acad Sci USA 95:3275-3280

138. Lauer D, Reichenbach A, Birkenmeier G (2001) Alpha 2macroglobulin-mediated degradation of amyloid beta 1-42: a mechanism to enhance amyloid beta catabolism. Exp Neurol 167:385-392

139. Narita M, Holtzman DM, Schwartz AL, Bu G (1997) Alpha2macroglobulin complexes with and mediates the endocytosis of beta-amyloid peptide via cell surface low-density lipoprotein receptor-related protein. J Neurochem 69:1904-1911

140. Emsley J, White HE, O'Hara BP, Oliva G, Srinivasan N, Tickle IJ, Blundell TL, Pepys MB, Wood SP (1994) Structure of pentameric human serum amyloid $\mathrm{P}$ component. Nature 367:338-345

141. McGeer EG, Yasojima K, Schwab C, McGeer PL (2001) The pentraxins: possible role in Alzheimer's disease and other innate inflammatory diseases. Neurobiol Aging 22:843-848

142. Ying SC, Gewurz AT, Jiang H, Gewurz H (1993) Human serum amyloid $\mathrm{P}$ component oligomers bind and activate the classical complement pathway via residues $14-26$ and $76-92$ of the A chain collagen-like region of C1q. J Immunol 150:169-176

143. Sappino AP, Madani R, Huarte J, Belin D, Kiss JZ, Wohlwend A, Vassalli JD (1993) Extracellular proteolysis in the adult murine brain. J Clin Invest 92:679-685

144. Kingston IB, Castro MJ, Anderson S (1995) In vitro stimulation of tissue-type plasminogen activator by Alzheimer amyloid betapeptide analogues. Nat Med 1:138-142

145. Tucker HM, Kihiko-Ehmann M, Wright S, Rydel RE, Estus S (2000) Tissue plasminogen activator requires plasminogen to modulate amyloid-beta neurotoxicity and deposition. J Neurochem 75:2172-2177
146. Melchor JP, Pawlak R, Strickland S (2003) The tissue plasminogen activator-plasminogen proteolytic cascade accelerates amyloid-beta (Abeta) degradation and inhibits Abeta-induced neurodegeneration. J Neurosci 23:8867-8871

147. Kwiatkowski DJ, Stossel TP, Orkin SH, Mole JE, Colten HR, Yin HL (1986) Plasma and cytoplasmic gelsolins are encoded by a single gene and contain a duplicated actin-binding domain. Nature 323:455-458

148. Kwiatkowski DJ, Mehl R, Yin HL (1988) Genomic organization and biosynthesis of secreted and cytoplasmic forms of gelsolin. J Cell Biol 106:375-384

149. Chauhan VP, Ray I, Chauhan A, Wisniewski HM (1999) Binding of gelsolin, a secretory protein, to amyloid beta-protein. Biochem Biophys Res Commun 258:241-246

150. Ray I, Chauhan A, Wegiel J, Chauhan VP (2000) Gelsolin inhibits the fibrillization of amyloid beta-protein, and also defibrillizes its preformed fibrils. Brain Res 853:344-351

151. Qiao H, Koya RC, Nakagawa K, Tanaka H, Fujita H, Takimoto M, Kuzumaki N (2005) Inhibition of Alzheimer's amyloid-beta peptide-induced reduction of mitochondrial membrane potential and neurotoxicity by gelsolin. Neurobiol Aging 26:849-855

152. Naiki H, Nakakuki K (1996) First-order kinetic model of Alzheimer's beta-amyloid fibril extension in vitro. Lab Invest 74:374-383

153. Hayashi H, Kimura N, Yamaguchi H, Hasegawa K, Yokoseki T, Shibata M, Yamamoto N, Michikawa M, Yoshikawa Y, Terao K, Matsuzaki K, Lemere CA, Selkoe DJ, Naiki H, Yanagisawa K (2004) A seed for Alzheimer amyloid in the brain. J Neurosci 24:4894-4902

154. Kakio A, Nishimoto SI, Yanagisawa K, Kozutsumi Y, Matsuzaki K (2001) Cholesterol-dependent formation of GM1 gangliosidebound amyloid beta-protein, an endogenous seed for Alzheimer amyloid. J Biol Chem 276:24985-24990

155. Kawarabayashi T, Shoji M, Younkin LH, Wen-Lang L, Dickson DW, Murakami T, Matsubara E, Abe K, Ashe KH, Younkin SG (2004) Dimeric amyloid beta protein rapidly accumulates in lipid rafts followed by apolipoprotein $\mathrm{E}$ and phosphorylated tau accumulation in the Tg2576 mouse model of Alzheimer's disease. J Neurosci 24:3801-3809

156. Parton RG (1994) Ultrastructural localization of gangliosides; GM1 is concentrated in caveolae. J Histochem Cytochem 42:155-166

157. Greenfield JP, Tsai J, Gouras GK, Hai B, Thinakaran G, Checler F, Sisodia SS, Greengard P, Xu H (1999) Endoplasmic reticulum and trans-Golgi network generate distinct populations of Alzheimer beta-amyloid peptides. Proc Natl Acad Sci USA 96:742-747

158. Hartmann T, Bieger SC, Bruhl B, Tienari PJ, Ida N, Allsop D, Roberts GW, Masters CL, Dotti CG, Unsicker K, Beyreuther K (1997) Distinct sites of intracellular production for Alzheimer's disease A beta40/42 amyloid peptides. Nat Med 3:1016-1020

159. Xu H, Sweeney D, Wang R, Thinakaran G, Lo AC, Sisodia SS, Greengard P, Gandy S (1997) Generation of Alzheimer betaamyloid protein in the trans-Golgi network in the apparent absence of vesicle formation. Proc Natl Acad Sci USA 94:3748-3752

160. Gouras GK, Tsai J, Naslund J, Vincent B, Edgar M, Checler F, Greenfield JP, Haroutunian V, Buxbaum JD, Xu H, Greengard P, Relkin NR (2000) Intraneuronal Abeta42 accumulation in human brain. Am J Pathol 156:15-20

161. LaFerla FM, Troncoso JC, Strickland DK, Kawas CH, Jay G (1997) Neuronal cell death in Alzheimer's disease correlates with apoE uptake and intracellular Abeta stabilization. J Clin Invest 100:310-320

162. Oddo S, Caccamo A, Shepherd JD, Murphy MP, Golde TE, Kayed R, Metherate R, Mattson MP, Akbari Y, LaFerla FM (2003) Triple-transgenic model of Alzheimer's disease with 
plaques and tangles: intracellular Abeta and synaptic dysfunction. Neuron 39:409-421

163. Yan SD, Fu J, Soto C, Chen X, Zhu H, Al Mohanna F, Collison K, Zhu A, Stern E, Saido T, Tohyama M, Ogawa S, Roher A, Stern D (1997) An intracellular protein that binds amyloid-beta peptide and mediates neurotoxicity in Alzheimer's disease. Nature 389:689-695

164. Yan SD, Stern DM (2005) Mitochondrial dysfunction and Alzheimer's disease: role of amyloid-beta peptide alcohol dehydrogenase (ABAD). Int J Exp Pathol 86:161-171

165. Yang Y, Turner RS, Gaut JR (1998) The chaperone BiP/GRP78 binds to amyloid precursor protein and decreases Abeta40 and Abeta42 secretion. J Biol Chem 273:25552-25555

166. Fonte V, Kapulkin V, Taft A, Fluet A, Friedman D, Link CD (2002) Interaction of intracellular beta amyloid peptide with chaperone proteins. Proc Natl Acad Sci USA 99:9439-9444

167. Magrane J, Smith RC, Walsh K, Querfurth HW (2004) Heat shock protein 70 participates in the neuroprotective response to intracellularly expressed beta-amyloid in neurons. J Neurosci 24:1700-1706.

168. Perez N, Sugar J, Charya S, Johnson G, Merril C, Bierer L, Perl D, Haroutunian V, Wallace W (1991) Increased synthesis and accumulation of heat shock 70 proteins in Alzheimer's disease. Brain Res Mol Brain Res 11:249-254

169. Hamos JE, Oblas B, Pulaski-Salo D, Welch WJ, Bole DG, Drachman DA (1991) Expression of heat shock proteins in Alzheimer's disease. Neurology 41:345-350

170. Kitamura Y, Nomura Y (2003) Stress proteins and glial functions: possible therapeutic targets for neurodegenerative disorders. Pharmacol Ther 97:35-53

171. Anthony SG, Schipper HM, Tavares R, Hovanesian V, Cortez SC, Stopa EG, Johanson CE (2003) Stress protein expression in the Alzheimer-diseased choroid plexus. J Alzheimers Dis 5:171-177

172. Dou F, Netzer WJ, Tanemura K, Li F, Hartl FU, Takashima A, Gouras GK, Greengard P, Xu H (2003) Chaperones increase association of tau protein with microtubules. Proc Natl Acad Sci USA 100:721-726

173. Shimura H, Schwartz D, Gygi SP, Kosik KS (2004) CHIP-Hsc70 complex ubiquitinates phosphorylated tau and enhances cell survival. J Biol Chem 279:4869-4876

174. Schuller E, Gulesserian T, Seidl R, Cairns N, Lube G (2001) Brain t-complex polypeptide 1 (TCP-1) related to its natural substrate beta1 tubulin is decreased in Alzheimer's disease. Life Sci 69:263-270

175. Shibata M, Yamada S, Kumar SR, Calero M, Bading J, Frangione B, Holtzman DM, Miller CA, Strickland DK, Ghiso J, Zlokovic BV (2000) Clearance of Alzheimer's amyloid-ss(140) peptide from brain by LDL receptor-related protein-1 at the blood-brain barrier. J Clin Invest 106:1489-1499

176. Deane R, Du YS, Submamaryan RK, LaRue B, Jovanovic S, Hogg E, Welch D, Manness L, Lin C, Yu J, Zhu H, Ghiso J, Frangione B, Stern A, Schmidt AM, Armstrong DL, Arnold B, Liliensiek B, Nawroth P, Hofman F, Kindy M, Stern D, Zlokovic B (2003) RAGE mediates amyloid-beta peptide transport across the bloodbrain barrier and accumulation in brain. Nat Med 9:907-913

177. Mackic JB, Stins M, McComb JG, Calero M, Ghiso J, Kim KS, Yan SD, Stern D, Schmidt AM, Frangione B, Zlokovic BV (1998) Human blood-brain barrier receptors for Alzheimer's amyloid-beta 1- 40. Asymmetrical binding, endocytosis, and transcytosis at the apical side of brain microvascular endothelial cell monolayer. J Clin Invest 102:734-743

178. Zlokovic BV (2005) Neurovascular mechanisms of Alzheimer's neurodegeneration. Trends Neurosci 28:202-208

179. Ruiz J, Kouiavskaia D, Migliorini M, Robinson S, Saenko EL, Gorlatova N, Li D, Lawrence D, Hyman BT, Weisgraber KH, Strickland DK (2005) The apoE isoform binding properties of the VLDL receptor reveal marked differences from LRP and the LDL receptor. J Lipid Res 46:1721-1731

180. DeMattos RB, Bales KR, Cummins DJ, Dodart JC, Paul SM, Holtzman DM (2001) Peripheral anti-A beta antibody alters CNS and plasma A beta clearance and decreases brain A beta burden in a mouse model of Alzheimer's disease. Proc Natl Acad Sci USA 98:8850-8855

181. DeMattos RB, Bales KR, Cummins DJ, Paul SM, Holtzman DM (2002) Brain to plasma amyloid-beta efflux: a measure of brain amyloid burden in a mouse model of Alzheimer's disease. Science 295:2264-2267

182. Bacskai BJ, Kajdasz ST, McLellan ME, Games D, Seubert P, Schenk D, Hyman BT (2002) Non-Fc-mediated mechanisms are involved in clearance of amyloid-beta in vivo by immunotherapy. J Neurosci 22:7873-7878

183. Hock C, Konietzko U, Streffer JR, Tracy J, Signorell A, MullerTillmanns B, Lemke U, Henke K, Moritz E, Garcia E, Wollmer MA, Umbricht D, de Quervain DJ, Hofmann M, Maddalena A, Papassotiropoulos A, Nitsch RM (2003) Antibodies against betaamyloid slow cognitive decline in Alzheimer's disease. Neuron 38:547-554

184. Matsuoka Y, Saito M, LaFrancois J, Saito M, Gaynor K, Olm V, Wang L, Casey E, Lu Y, Shiratori C., Lemere C, Duff K (2003) Novel therapeutic approach for the treatment of Alzheimer's disease by peripheral administration of agents with an affinity to beta-amyloid. J Neurosci 23:29-33

185. Akiyama H, Barger S, Barnum S, Bradt B, Bauer J, Cole GM, Cooper NR, Eikelenboom P, Emmerling M, Fiebich BL, Finch CE, Frautschy S, Griffin WS, Hampel H, Hull M, Landreth G, Lue L, Mrak R, Mackenzie IR, McGeer PL, O'Banion MK, Pachter J, Pasinetti G, Plata-Salaman C, Rogers J, Rydel R, Shen Y, Streit W, Strohmeyer R, Tooyoma I, Van Muiswinkel FL, Veerhuis R, Walker D, Webster S, Wegrzyniak B, Wenk G, Wyss-Coray T (2000) Inflammation and Alzheimer's disease. Neurobiol Aging 21:383-421

186. DeWitt DA, Perry G, Cohen M, Doller C, Silver J (1998) Astrocytes regulate microglial phagocytosis of senile plaque cores of Alzheimer's disease. Exp Neurol 149:329-340

187. McGeer PL, McGeer EG (1995) The inflammatory response system of brain: implications for therapy of Alzheimer and other neurodegenerative diseases. Brain Res Brain Res Rev 21:195-218

188. Kakimura J, Kitamura Y, Taniguchi T, Shimohama S, GebickeHaerter PJ (2001) Bip/GRP78-induced production of cytokines and uptake of amyloid-beta(1-42) peptide in microglia. Biochem Biophys Res Commun 281:6-10

189. Kakimura J, Kitamura Y, Takata K, Umeki M, Suzuki S, Shibagaki K, Taniguchi T, Nomura Y, Gebicke-Haerter PJ, Smith MA, Perry G, Shimohama S (2002) Microglial activation and amyloid-beta clearance induced by exogenous heat-shock proteins. FASEB J 16:601-603 